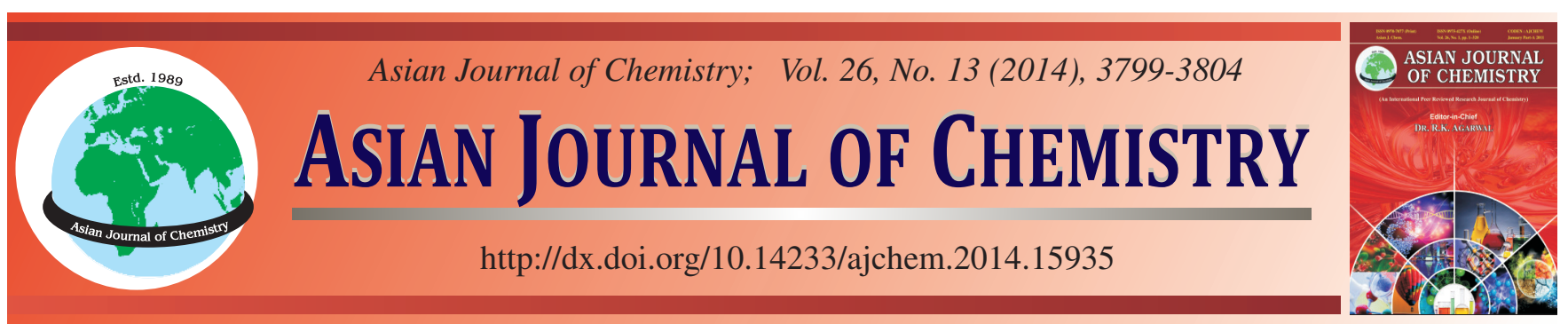

\title{
Simultaneous Estimation of Quinapril Hydrochloride and Hydrochlorothiazide from Pharmaceutical Formulation by Using UV, IR and RP-HPLC
}

\author{
Vandana Tukaram Gawande, Pankaj Birajlal Miniyar, Deepali Dattatray Bhandari, \\ Manasi Kailas Ghag, Dhananjaysingh Bhikamsingh Rajput and Anand Avinash Mahajan*
}

Department of Pharmaceutical Chemistry, STES's Sinhgad Institute of Pharmacy, Off. Smt. Kashibai Navale Hospital, Narhe, Pune-411041, India *Corresponding author: Fax: +91 20 66831816; Tel: +91 20 66831802/50; E-mail: anand_mahajan@yahoo.com

\begin{abstract}
The objective of present investigation was to develop and validate assay methods for simultaneous estimation of quinapril hydrochloride and hydrochlorothiazide in combined dosage form by using three different analytical approaches viz. UV, FT-IR and RP-HPLC. Drugs were estimated by dual wavelength method and calibration curve methods by using UV and FT-IR spectrophotometer, respectively. The stability indicating assay method was developed by using HPLC. The stress degradation study was carried out according to International Conference on Harmonization (ICH) guideline Q1A (R2). Chromatographic separation was carried out on HIQ-Sil $(150 \times 4.6 \mathrm{~mm}, 5 \mu \mathrm{m})$ column using $0.01 \mathrm{M} \mathrm{KH}_{2} \mathrm{PO}_{4}$ buffer ( $\mathrm{pH} 3.5$, adjusted with orthophosphoric acid): methanol as mobile phase in gradient elution mode.
\end{abstract}

Keywords: Dual wavelength, DRIFTS, Hydrochlorothiazide, Quinapril hydrochloride, RP-HPLC.

\section{INTRODUCTION}

Hypertension is an important contributor to the risk of cardiovascular disease and death, yet success in achieving blood pressure control has been limited. Most of the patients require 2 or more medications to control their blood pressure. Current guidelines for treatment of hypertension also support the first-line use of combination therapy in many patients. Initiating therapy with a RAS (renin angiotensin system) inhibitor-based combination can reduce blood pressure and cardiovascular risk and may be more effective for majority of patients than traditional combinations such as a $\beta$-blocker with a diuretic ${ }^{1}$. Quinapril hydrochloride (QUINA) is an angiotensinconverting enzyme inhibitor (ACE inhibitor) used in the treatment of hypertension and congestive heart failure. Chemically it is [3S-[2[R* $\left.\left.\left.\left(R^{*}\right)\right], 3 R^{*}\right]\right](S)-2-[(S)-N-[(S)-1$-carboxy-3-phenylpropryl]alany]-1,2,3,4-tetrahydro-isoquinoline carboxylic acid, 1- ethyl ester, monohydrochloride. Monogrph of QUINA is included in $\mathrm{USP}^{2}$ [Fig. 1 (a)].

Hydrochlorothiazide (HCTZ) is a thiazide diuretic most commonly prescribed for hypertension and mild heart failure. Chemically it is 6-chloro-3,4-dihydro- $2 \mathrm{H}$-1,2,4-benzothiadiazine-7-sulphonamide-1,1-dioxide. Monograph of HCTZ is included in $\mathrm{IP}^{3}, \mathrm{EP}^{4}$ and $\mathrm{USP}^{5}$.

Currently both drugs are available in combination under brand names of Accupro Comp, Accuzide, Koretic, Co-Quinapril and Accuretic. Various UV-visible spectrophotometric (UV) $)^{6-8}$, high performance thin layer chromatographic (HPTLC) ${ }^{9}$ and high performance liquid chromatographic (HPLC) ${ }^{10-14}$ methods have been reported for quantitative determination of QUINA and HCTZ in standalone and combination products. The literature also shows few methods reported for simultaneous estimation of QUINA and HCTZ in fixed dose combination ${ }^{15-17}$. Though these methods already exist but none of the methods reported simultaneous quantitative estimation of QUINA and HCTZ by diffuse reflectance using Fourier transform infrared spectrophotometry (DRIFTS), dual wavelength method using UV and stability indicating assay method using HPLC. Hence attempt was made towards development of assay method for simultaneous estimation of QUINA and HCTZ using DRIFTS, UV and HPLC. Green approach is used in the method developed by using DRIFTS, which is solvent free method of analysis. UV method was found to be faster. Method developed using HPLC was stability indicating.

\section{EXPERIMENTAL}

Quinapril hydrochloride (QUINA) and hydrochlorothiazide (HCTZ) were obtained as gift samples from Aurobindo Pharmaceuticals Ltd., Hyderabad and Macleods Pharmaceuticals Ltd., Mumbai respectively. Potassium bromide (IR grade) was purchased from Qualigenes Fine Chemicals (Mumbai, India). Analytical reagent (AR) grade sodium hydroxide and hydro- 
<smiles>CCOC(=O)[C@H](CCc1ccccc1)N[C@@H](C)C(=O)N1Cc2ccccc2C[C@H]1C(=O)O</smiles>

(a)<smiles>NS(=O)(=O)c1cc2c(cc1Cl)NCNS2(=O)=O</smiles>

(b)

Fig. 1. Structure of (a) quinapril hydrochloride (QUINA) and (b) hydrochlorothiazide (HCTZ)

chloric acid were purchased from Qualigens Fine Chemicals (Mumbai, India). Formic acid, hydrogen peroxide $\left(\mathrm{H}_{2} \mathrm{O}_{2}\right)$ were purchased from S.D. Fine-Chem Ltd. (Mumbai, India). HPLC grade acetonitrile and methanol were purchased from S.D. Fine-Chem Ltd. (Mumbai, India). HPLC grade double distilled water was produced using quartz double distillation assembly from Lab-Sil Instruments (Bangalore, India). Marketed formulation (Acupil-H, Macleods Pharmaceutical Ltd., Mumbai) was purchased from local drug store.

FT-IR spectra were recorded by using Jasco 4100 FT-IR spectrophotometer DRIFTS system. UV spectra were recorded by using Jasco V-630 UV-visible double beam spectrophotometer. The output signals of FT-IR and UV spectrophotometer were monitored by using Spectra Manager software.

Chromatographic work was performed on Shimadzu Prominence binary gradient system (LC 20 AD) fitted with 20 $\mu \mathrm{L}$ injection loop and photo diode array detector (PDA) (SPD M20A). The output signals were monitored and processed using LC solution multi PDA software.

Degradation studies were carried out on water bath (MetaLab, Mumbai) equipped with thermostat for temperature control. A hot air oven (Scientico, Mumbai) was used to carry out solid state thermal stress studies. Photostability studies were carried out in photostability chamber (Thermolab Scientific Equipments Pvt. Ltd., India). The photostability chamber consists of two ultraviolet (UV) and four white fluorescent lamps; both of these lamps were kept on during the photostability study. Calibrated lux and UV meters were used to measure visible illumination and near UV energy respectively. The data was recorded and processed using Stability V7.2T software on Dell computer. The separation was carried out on $\mathrm{C}_{18}$ HIQ-sil $(150 \times 4.6 \mathrm{~mm}$, particle size $5 \mu \mathrm{m})$ column at flow rate of $1 \mathrm{~mL} \mathrm{~min}^{-1}$ and wavelength maximum $215 \mathrm{~nm}$. The mobile phase was composed of $0.01 \mathrm{M} \mathrm{KH}_{2} \mathrm{PO}_{4}$ buffer $\mathrm{pH} 3.5$ (adjusted with orthophosphoric acid): methanol which was run in gradient mode as outlined in Table- 1 . The mobile phase in the ratio $(50: 50 \mathrm{v} / \mathrm{v})$ was used for diluting the samples.

The $\mathrm{pH}$ of mobile phase was adjusted by using $\mathrm{pH}$ meter (Controlled Dynamics, India). Other equipments used were sonicator (Spectralab UCB 30) and analytical balance (Precissa XR 205 SMDR).

\begin{tabular}{ccc}
\multicolumn{3}{c}{ TABLE-1 } \\
GRADIENT ELUTION PROGRAMME \\
\hline Time $(\mathrm{min})$ & Buffer $\left(\mathrm{KH}_{2} \mathrm{PO}_{4}, \mathrm{pH}=3.5\right)(\%)$ & Methanol (\%) \\
\hline 0.01 & 43 & 57 \\
20 & 23 & 77 \\
30 & 43 & 57 \\
\hline
\end{tabular}

\section{DRIFTS method}

Calibration curve method: Calibration curve method was used for quantitative analysis of QUINA and HCTZ. In this technique FT-IR spectrum of the drug was recorded in the range of 4000-400 $\mathrm{cm}^{-1}$ and corresponding area of the absorption peak was measured with the help of software program. The absorption peak selected for one particular drug was sufficiently different than that of another drug to avoid interference. The overlain spectra of QUINA and HCTZ is shown in Fig. 2. The quantitative determination of QUINA and HCTZ were carried out by selecting peak area at 1680-

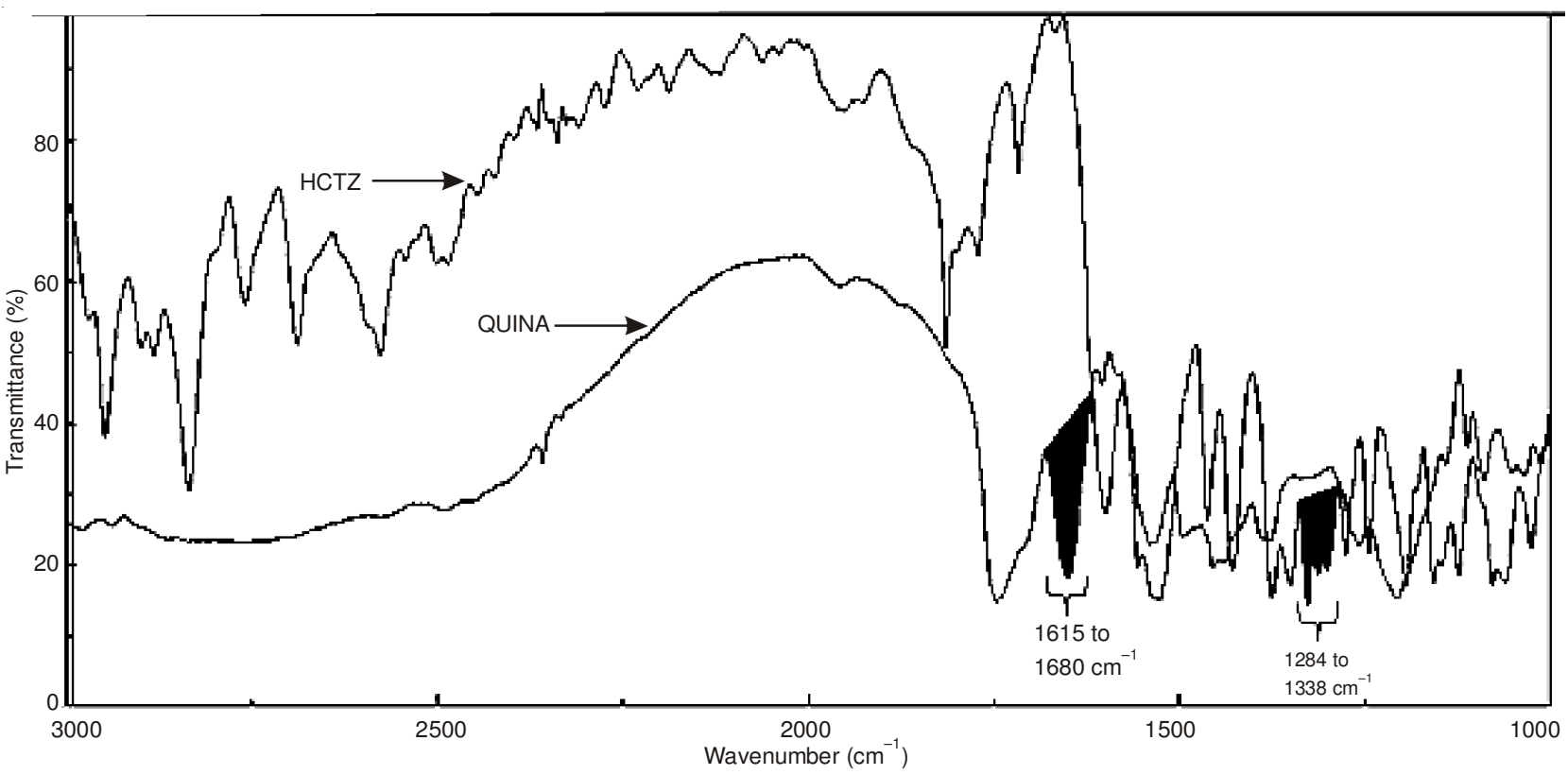

Fig. 2. Overlain FT-IR spectra for QUINA and HCTZ 
$1615 \mathrm{~cm}^{-1}(\mathrm{C}=\mathrm{O}$ stretch $)$ and $1338-1284 \mathrm{~cm}^{-1}(\mathrm{O}=\mathrm{S}=\mathrm{O}$ stretch$)$, respectively.

\section{Method validation}

Linearity: The linearity of QUINA and HCTZ was determined at six concentration levels of 10-30 mg/50 mg Kbr for both the drugs. The samples were prepared in triplicate. The peak area versus concentration data was processed by leastsquare linear regression analysis

Precision: The intra-day and inter-day precision was carried out by analyzing both the drugs (10, 14 and $18 \mathrm{mg} / 50 \mathrm{mg}$ Kbr) drug mixtures were prepared in triplicate on same day and on consecutive days.

Accuracy: The accuracy of the method was determined by conducting recovery studies of pure drug by standard addition method. It was carried out by spiking mixture of drugs (10 mg/50 mg Kbr) with three known concentrations of both $\operatorname{drug}(8,10$ and $12 \mathrm{mg} / 50 \mathrm{mg} \mathrm{Kbr})$ in triplicate and then determining per cent recovery of added drug.

Assay of marketed formulation: Twenty tablets containing QUINA (10 mg) and HCTZ (12.5 mg) were weighed. Average weight of the tablet was calculated. The powder (252 $\mathrm{mg}$ ) equivalent to $10 \mathrm{mg}$ of QUINA and $12.5 \mathrm{mg}$ of HCTZ was weighed. To weighed quantity of powder, IR grade potassium bromide was added up to $50 \mathrm{mg}$. This mixture was triturated in agate mortar and pestle and was placed in cup of diffuse reflectance assembly. After recording spectrum, peak areas of selected peak regions were measured to determine concentration of both the drugs.

Spectrophotometric method: Dual wavelength method ${ }^{18}$ was used to calculate the unknown concentration of a component of interest from multicomponent formulation. In this method two such wavelengths are selected where, absorbance difference for one of the component is directly proportional to its concentration while absorbance difference for another component equals to zero thus interference due to other component is avoided. For estimation of QUINA two wavelengths (220 and $230 \mathrm{~nm}$ ) were selected where QUINA shows significant difference in absorbance while HCTZ shows same absorbance, hence absorbance difference of HCTZ is zero. This condition will avoid interference due to HCTZ in the estimation of QUINA. For estimation of HCTZ, $261 \mathrm{~nm}$ wavelength was selected where QUINA will not show any interference due to its zero absorbance at this wavelength. The overlain spectra of QUINA and HCTZ is shown in Fig. 3.

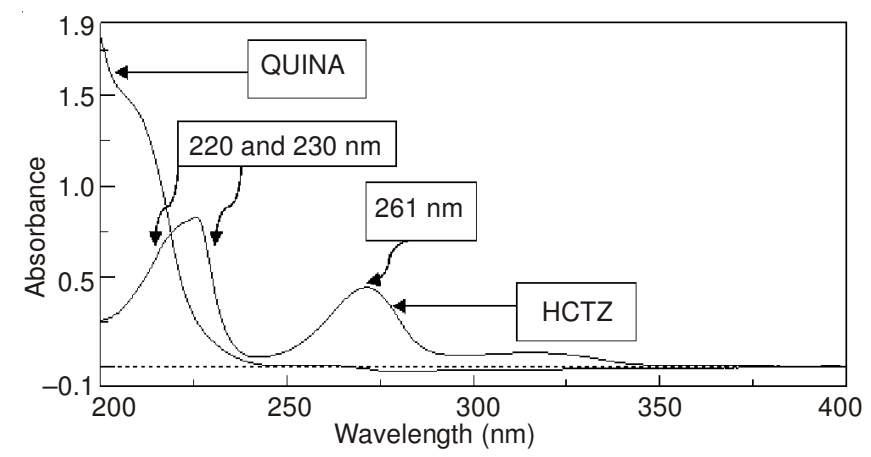

Fig. 3. Overlain spectra of QUINA and HCTZ (15 $\mu \mathrm{g} / \mathrm{mL}$ each)
The concentration of individual drug was determined by using following equation

For QUINA y $=0.038 \mathrm{x}+0.263(\mathrm{y}=$ absorbance difference at 220 and $230 \mathrm{~nm}, \mathrm{x}=$ concentration in $\mu \mathrm{g} / \mathrm{mL})$

For HCTZ $y=0.043 x+0.010(y=$ absorbance at $261 \mathrm{~nm}$, $\mathrm{x}=$ concentration in $\mu \mathrm{g} / \mathrm{mL}$ )

Method validation: The developed method was validated as per ICH guideline Q2 (R1) ${ }^{19}$.

Linearity: Linearity of QUINA was determined by plotting absorbance difference values at 220 and $230 \mathrm{~nm}$ vs. concentration. Whereas linearity of HCTZ was determined at 261 $\mathrm{nm}$ wavelength. The linearity test solutions for QUINA (10$50 \mu \mathrm{g} \mathrm{mL}^{-1}$ ) and $\mathrm{HCTZ}$ ( 5 to $25 \mu \mathrm{g} \mathrm{mL}^{-1}$ ) were prepared using methanol at five concentration levels from the stock solution of QUINA $\left(1000 \mu \mathrm{g} \mathrm{mL}^{-1}\right)$ and HCTZ $\left(1000 \mu \mathrm{g} \mathrm{mL}^{-1}\right)$, respectively. The solutions were prepared in triplicate. The absorbance versus concentration data was processed by least-square linear regression analysis.

Precision: The intra-day and inter-day precision was carried out by analyzing QUINA (20,30,40 $\left.\mu \mathrm{g} \mathrm{mL}^{-1}\right)$ and HCTZ (10, $\left.15,20 \mu \mathrm{g} \mathrm{mL}^{-1}\right)$. Drug solutions were prepared in triplicate on same day and on consecutive days.

Accuracy: The accuracy of the method was determined by conducting recovery studies of pure drug by standard addition method. It was carried out by spiking mixture of drugs (QUINA $10 \mu \mathrm{g} \mathrm{mL}^{-1}$ and HCTZ $10 \mu \mathrm{g} \mathrm{mL}^{-1}$ ) with three known concentrations of standard drugs QUINA $\left(8,10\right.$ and $\left.12 \mu \mathrm{g} \mathrm{mL}^{-1}\right)$ and $\operatorname{HCTZ}\left(8,10\right.$ and $\left.12 \mu \mathrm{g} \mathrm{mL}^{-1}\right)$. Drug solutions were prepared in triplicate and per cent recovery of added drug was determined.

Assay of marketed formulation: Twenty tablets were weighed and crushed to obtain a fine powder. Tablet powder equivalent to $10 \mathrm{mg}$ of QUINA and $12.5 \mathrm{mg}$ of HCTZ was transferred to $25 \mathrm{~mL}$ volumetric flask. To it $15 \mathrm{~mL}$ of methanol was added and sonicated for $15 \mathrm{~min}$. The volume was made up to the mark by using methanol. The resulting solution was filtered through Whatman filter paper no. 42 and filtrate was appropriately diluted with methanol to get concentration of $10 \mu \mathrm{g} / \mathrm{mL}$ of QUINA and $12.5 \mu \mathrm{g} / \mathrm{mL}$ of HCTZ. The absorbance was measured at the selected wavelengths and concentrations were determined. The analysis was carried out in triplicate.

\section{RP-HPLC method}

Stability indicating method: Stability indicating assay methods (SIAMs) can be specific or selective. Specific stability indicating assay method is developed to measure the active ingredient in the presence of all degradation products, excipients and additives expected to be present in the formulation. Selective stability indicating method is developed to measure active ingredients as well as degradation products in presence of excipients and additives ${ }^{20}$.

Regulatory ICH guidelines Q1AR2 ${ }^{21}, \mathrm{Q}^{3} \mathrm{BR} 2^{22}, \mathrm{Q}^{2} \mathrm{~A}^{23}$ and FDA 21 CFR section $211^{24}$ explicitly indicate the need of stress testing, identification of degradation products and development of validated stability indicating assay method. However these guidelines do not provide any specific practical methodology for stress testing ${ }^{25}$. Hence, degradation conditions, concentration of degrading agent and time of degradation 
are to be determined empirically to achieve 10 to $15 \%$ of degradation of active ingredient.

Stress studies: Stress studies were carried out on each drug (QUINA and HCTZ) under variety of stress conditions i.e. acidic, alkaline and neutral hydrolysis, oxidation, heat and photolysis. Hydrolytic decomposition of drugs was carried out separately under acidic, alkaline and neutral condition by heating $1 \mathrm{~mL}$ each of $\mathrm{HCl}(1 \mathrm{~N}), \mathrm{NaOH}(1 \mathrm{~N})$ and water with $1 \mathrm{~mL}$ of $1000 \mathrm{mg} \mathrm{mL}^{-1} \mathrm{drug}$ at $80^{\circ} \mathrm{C}$ for different time intervals. Samples were neutralized after required exposure. Samples treated with acid were neutralized by using equal strength of base and vice versa. Each drug solution, $1 \mathrm{~mL}$ of $1000 \mathrm{mg}$ $\mathrm{mL}^{-1}$ was treated with $1 \mathrm{~mL}$ of $15 \% \mathrm{H}_{2} \mathrm{O}_{2}$ at $80{ }^{\circ} \mathrm{C}$ for different time intervals for oxidative stress. Thermal and photo degradation was carried out using solid drug. In case of thermal degradation, the solid drug was heated in an oven within sealed glass ampoule at $70{ }^{\circ} \mathrm{C}$ for a period of three days. In the same way the control sample was maintained outside of the oven at room temperature. During photo degradation solid drug was exposed to 1.25 million lux hours of fluorescent light and 200 Watt hours/square meter of UV light along with control sample, which was covered with aluminum foil. Samples after required exposure under different stress conditions were diluted with the help of diluent to predetermined concentration of original $\operatorname{drug}\left(100 \mu \mathrm{g} \mathrm{mL}^{-1}\right)$ and injected in HPLC for analysis.

Preparation of samples for HPLC: The samples were diluted up to $10 \mathrm{~mL}$ with diluent in case of acid, base, neutral and oxidative stress to produce concentration of $100 \mu \mathrm{g} \mathrm{mL}^{-1}$ of original drug. The solid samples which were exposed for photo and thermal stress were also weighed appropriately and diluted with suitable quantity of diluent to produce $100 \mu \mathrm{g}$ $\mathrm{mL}^{-1}$ of original drug.

Development of stability indicating assay (SIAM) method: Initial method development was carried out by using reverse phase chromatographic system to monitor degradation behaviour of individual drug (QUINA and HCTZ). HiQsil C18 $(150 \times 4.6 \mathrm{~mm}, 5 \mu \mathrm{m})$ column was used as stationary phase. The $\mathrm{pK}_{\alpha}$ values of QUINA and HCTZ are 3.7, 5.2 and 7.9, respectively. It was observed that at $\mathrm{pH} 3.5$, QUINA and HCTZ showed desirable retention behaviour in reversed phase chromatographic system. Under different stress conditions QUINA and HCTZ generated polar as well as non-polar degradants. Initially HPLC analysis was performed on all stressed samples individually and then on mixture of all stressed samples. Gradient elution system was employed; different modifications in gradient program were carried out to obtain better resolution among the degradants and between drug and degradants. The best separation was achieved by using a mobile phase composed of $0.01 \mathrm{M} \mathrm{KH}_{2} \mathrm{PO}_{4}$ buffer $\mathrm{pH} 3.5$ (adjusted with orthophosphoric acid): methanol which was run in gradient mode as outlined in Table- 1 . The flow rate was $1 \mathrm{~mL} / \mathrm{min}$ and detection wavelength $215 \mathrm{~nm}$.

Method validation: The developed method was validated as per ICH guideline Q2 (R1) ${ }^{19}$.

Linearity: Linearity of QUINA and HCTZ was determined by plotting peak area versus concentration. The linearity test solutions for QUINA (2-10 $\mu \mathrm{g} \mathrm{mL}^{-1}$ ) and HCTZ (2.5 to $12.5 \mu \mathrm{g} \mathrm{mL}^{-1}$ ) were prepared from the stock solution of QUINA $\left(1000 \mu \mathrm{g} \mathrm{mL}^{-1}\right)$ and HCTZ $\left(1000 \mu \mathrm{g} \mathrm{mL}^{-1}\right)$ respectively. The solutions were diluted with the help of diluents (buffer: methanol, 50:50 v/v). The solutions were prepared in triplicate at five different concentration levels. The peak area versus concentration data was processed by least-square linear regression analysis.

Precision: The intra-day and inter-day precision was carried out by analyzing QUINA (4, 6, $\left.8 \mu \mathrm{g} \mathrm{mL}^{-1}\right)$ and HCTZ $\left(5,7.5,10 \mu \mathrm{g} \mathrm{mL}^{-1}\right)$. Drug solutions were prepared in triplicate on same day and on consecutive days.

Accuracy: The accuracy of the method was determined by conducting recovery studies of pure drug by standard addition method. It was carried out by spiking mixture of drugs (QUINA $4 \mu \mathrm{g} \mathrm{mL}^{-1}$ and HCTZ $5 \mu \mathrm{g} \mathrm{mL}^{-1}$ ) with three known concentrations of standard drugs QUINA $(3.2,4$ and $4.8 \mu \mathrm{g}$ $\left.\mathrm{mL}^{-1}\right)$ and $\mathrm{HCTZ}\left(4,5\right.$ and $\left.6 \mu \mathrm{g} \mathrm{mL}^{-1}\right)$. Drug solutions were prepared in triplicate and percent recovery of added drug was determined.

Assay of marketed formulation: Twenty tablets were weighed and crushed to obtain a fine powder. Tablet powder equivalent to $10 \mathrm{mg}$ of QUINA and $12.5 \mathrm{mg}$ of HCTZ was transferred to $25 \mathrm{~mL}$ volumetric flask. To it $15 \mathrm{~mL}$ of methanol was added and sonicated for $15 \mathrm{~min}$. The volume was made up to the mark by using methanol. The resulting solution was filtered through membrane filter $(0.45 \mu)$. The Filtrate was diluted with the help of diluent to get concentration of $10 \mu \mathrm{g} / \mathrm{mL}$

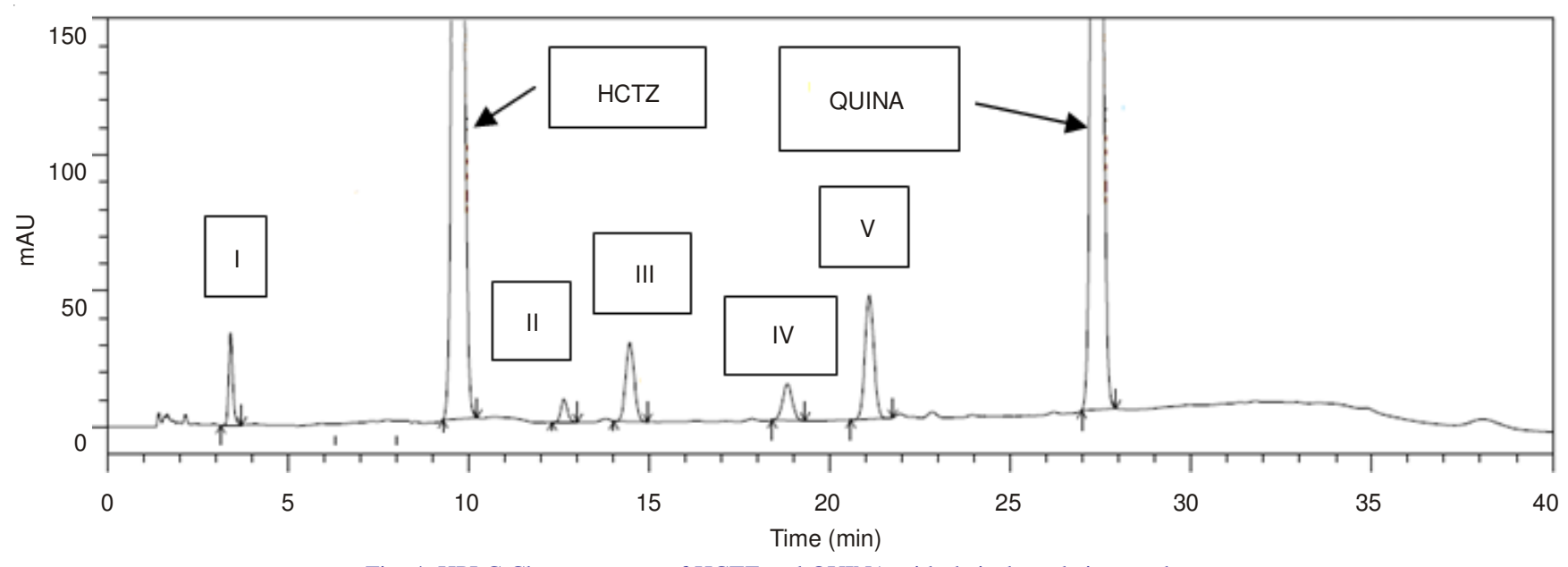

Fig. 4. HPLC Chromatogram of HCTZ and QUINA with their degradation products 
of QUINA and $12.5 \mu \mathrm{g} / \mathrm{mL}$ of HCTZ. Solutions were injected in HPLC system and peak areas were measured. The analysis was carried out in triplicate.

\section{RESULTS AND DISCUSSION}

DRIFTS-calibration curve method: The developed calibration curve method was validated as per ICH guidelines (Table-2) and successfully used for analysis of QUINA and HCTZ in marketed formulation (Table-3). The FT-IR spectrum of commercial tablet sample containing QUINA and HCTZ showed that the excipients do not show interference with drug peaks.

Spectrophotometric-dual wavelength method: The developed dual wavelength method was validated as per ICH guidelines (Table-2) and successfully used for analysis of QUINA and HCTZ in marketed formulation (Table-3). The UV spectrum of commercial tablet sample containing QUINA and HCTZ also confirm that the excipients do not show interference with drug absorption.

RP-HPLC-stability indicating assay method: The stress studies were carried out on both the drugs (QUINA and HCTZ). Both the drugs were subjected to hydrolysis (acidic, alkaline and neutral), oxidation, thermal stress and photolysis. The stress conditions were optimized to obtain degradation products after 15-20\% degradation of both the drugs (QUINA and HCTZ). The degradation products obtained under all the stress conditions were separated by using HPLC. The degradation products generated under different stress conditions carry the notations from $\mathrm{I}$ to $\mathrm{V}$ in accordance with the sequence in which peak appears from left to right on the HPLC chromatogram (Fig. 4). The results of the stress study are given in following Table-4.

The developed method was validated as per ICH guideline Q2 [R1]. The summary of the validation parameter is given in Table-2. The method was applied for analysis of marketed formulation. The assay results are given in Table-3.

\section{Conclusion}

The present research paper describes application of UV spectrophotometric method, FT-IR spectrophotometric method and HPLC method for determination of QUINA and HCTZ in fixed dose marketed formulation. The proposed methods are simple, specific, accurate and precise. The analyses of marketed formulation do not show any interference of additives and

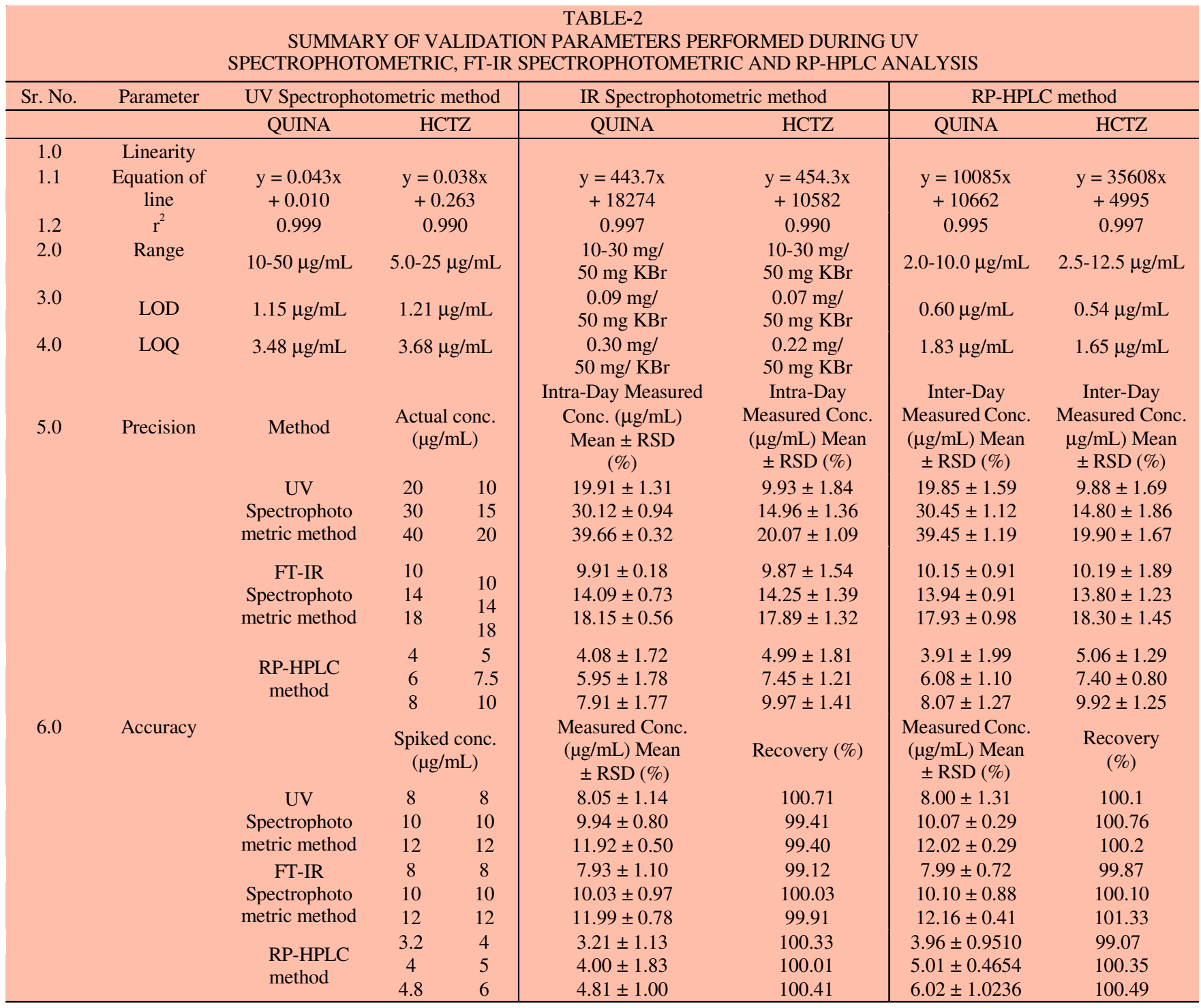




\begin{tabular}{|c|c|c|c|c|}
\hline \multicolumn{5}{|c|}{$\begin{array}{c}\text { TABLE-3 } \\
\text { RESULTS OF ANALYSIS OF TABLET FORMULATION }\end{array}$} \\
\hline Tablet formulation & \multicolumn{2}{|c|}{ Label claim/(mg per tablet $)$} & Amount of drug estimated & $\%$ of label claim Mean \pm R. S. D. (\%) \\
\hline \multirow{6}{*}{$\begin{array}{c}\text { Acupil-H } \\
\text { (Pfizer Limited, Mumbai) }\end{array}$} & \multirow[t]{3}{*}{ HCTZ- } & \multirow{3}{*}{12.50} & 12.50 & $100.00 \pm 0.78$ \\
\hline & & & 12.44 & $99.56 \pm 1.09$ \\
\hline & & & 12.45 & $99.66 \pm 0.58$ \\
\hline & \multirow[t]{3}{*}{ QUINA- } & & 9.87 & $98.78 \pm 0.90$ \\
\hline & & 10.00 & 10.04 & $100.42 \pm 0.81$ \\
\hline & & & 10.71 & $100.71 \pm 1.01$ \\
\hline
\end{tabular}

\begin{tabular}{|c|c|c|c|}
\hline \multicolumn{4}{|c|}{$\begin{array}{c}\text { TABLE-4 } \\
\text { SUMMERY OF DEGRADATION BEHAVIOUR OF HCTZ AND QUINA }\end{array}$} \\
\hline Sr. No. & Name of drug & $\begin{array}{l}\text { Stress condition } \\
\end{array}$ & Notation in chromatogram \\
\hline \multirow{6}{*}{1} & \multirow{6}{*}{ Quinapril hydrochloride } & Acid hydrolysis $(1 \mathrm{~N} \mathrm{HCl}) 80^{\circ} \mathrm{C}, 2.0 \mathrm{~h}$ & II and III \\
\hline & & Base hydrolysis $(1 \mathrm{~N} \mathrm{NaOH}) 80^{\circ} \mathrm{C}, 2.0 \mathrm{~h}$ & IV and $\mathrm{V}$ \\
\hline & & Neutral hydrolysis $80^{\circ} \mathrm{C}, 2.0 \mathrm{~h}$ & - \\
\hline & & Oxidative stress $\left(15 \% \mathrm{H}_{2} \mathrm{O}_{2}\right)$ & - \\
\hline & & Thermal stress $70^{\circ} \mathrm{C}, 3.0$ days & - \\
\hline & & Photolysis & - \\
\hline \multirow{6}{*}{2} & \multirow{6}{*}{ Hydrochlorothiazide } & Acid hydrolysis $(1 \mathrm{~N} \mathrm{HCl}) 80^{\circ} \mathrm{C}, 2.0 \mathrm{~h}$ & I \\
\hline & & Base hydrolysis $(1 \mathrm{~N} \mathrm{NaOH}) 80^{\circ} \mathrm{C}, 2.0 \mathrm{~h}$ & I \\
\hline & & Neutral hydrolysis $80^{\circ} \mathrm{C}, 2.0 \mathrm{~h}$ & I \\
\hline & & Oxidative stress $\left(15 \% \mathrm{H}_{2} \mathrm{O}_{2}\right)$ & I \\
\hline & & Thermal stress $70^{\circ} \mathrm{C}, 3.0$ days & - \\
\hline & & Photolysis & - \\
\hline
\end{tabular}

excipients. FT-IR analysis is green analytical technique where the analysis is carried out without use of organic solvents.

\section{REFERENCES}

1. M.E. Roberts and B.J. Epstein, J. Cardiovasc. Nurs., 24, 380 (2009).

2. U.S. Pharmacopoeia, 30/ NF25, U.S. Pharmacopoeial Convention, Rockville, MD, pp. 1689-1690 (2005).

3. Indian Pharmacopoeia Volume II, Govt. of India, New Delhi: Ministry of Health and Family Welfare, pp. 1194-1195 (2007).

4. European Pharmacopoeia, Convention on the Elaboration of European Pharmacopoeia, Vol. 2, pp. 1756-1757 (2004).

5. U.S. Pharmacopoeia 30/ NF25, U.S. Pharmacopoeial Convention, Rockville, MD, pp. 954-955 (2005).

6. R. Gangola, S. Kaushik and P. Sharma, J. Appl. Pharm. Sci., 1, 46 (2011).

7. A.T. Hemke, M.V. Bhure, K.S. Chouhan, K.R. Gupta and S.G. Wadodkar, E.-J. Chem., 7, 1156 (2010).

8. N. Jain, R. Jain, N. Thakur and B. Gupta, Int. J. Appl. Pharm., 2, 212 (2010).

9. K.R. Patel, S.A. Patel, D. Vinayc and R.N. Sonpal, Indian Res. J. Pharm., 2, 202 (2011).

10. S.T. Kumbhar, G.K. Chougule, V.S. Tegeli, G.B. Gajeli, Y.S. Thorat and U.S. Shivsharan, Int. J. Pharm. Sci. Drug Res., 3, 62 (2011).

11. K.S. Chouhan, M.V. Bhure, A.T. Hemke, K.R. Gupta and S.G. Wadodkar, Res. J. Pharm. Biol. Chem. Sci., 1, 81 (2010).

12. N. Devanaboyina, T. Satyanarayana and G.B. Rao, Res. J. Pharm. Biol. Chem. Sci., 3, 270 (2012).
13. A. Gumieniczek and H. Hopkala, Pharm. Acta Helv., 73, 183 (1998).

14. R.D. Sreenivas, M.K. Srinivasu, C.L. Narayana and G.O. Reddy, Indian Drugs, 37, 80 (2000).

15. V.A. Chatpalliwar, D.D. Patil, S.J. Surana and G.B. Bhavar, Indian J. Pharm. Sci., 70, 529 (2008).

16. M. Gandhimathi and T.K. Ravi, Indian J. Pharm. Sci., 71, 311 (2009).

17. E. Dinç and D. Baleanu, J. Braz. Chem. Soc., 18, 962 (2007).

18. R. Savithri, N.S. Bindu, P.S. Bhargavi, D.H. Theja and P. Ramalingam, Der Pharm. Sinica, 2, 251 (2011).

19. International Conference on Harmonization Triplicate, Guideline: Validation of Analytical Procedures Text and Methodology, Q2[R1], p. 1-13 (2005).

20. M. Bakshi and S. Singh, J. Pharm. Biomed. Anal., 28, 1011 (2002).

21. International Conference on Harmonization, Guidance for Industry: Stability Testing of New Drug Substances and Products, Q1A [R2] (1996).

22. International Conference on Harmonization, Impurities in New Drug Products, Q3B (R2) (2006).

23. International Conference on Harmonization, Test Procedures and Acceptance Criteria for New Drug Substances and New Drug Products: Chemical Substances, Q6A (2000).

24. Food and Drug Administration, Code of Federal Regulations Title 21, Section 211 (available on http://www.accessdata.fda.gov/scripts/cdrh/ cfdocs/cfcfr/cfrsearch.cfm).

25. S. Singh and M. Bakshi, Pharm. Tech. On-line, 24, 1 (2000). 